\title{
"SHARING ECONOMY" THE CASE OF AIRBNB IN NCR: AN HONESTLY SIGNIFICANT DIFFERENCE (HSD) TEST
}

\author{
Mary Vida L. Tumbali ${ }^{1 *}$ \\ 1 Ph.D. Commerce (Candidate), University of Santo Tomas, Graduate School, Philippines \\ Department of Tourism and Hospitality Management, Part-time Faculty University of the East, Manila \\ Philippines \\ Email: maryvidat@gmail.com,maryvida.tumbali.gs@ust.edu.ph \\ * Corresponding Author
}

\section{Article Info: \\ Article history: \\ Received date: 07.05 .2020 \\ Revised date: 10.06 .2020 \\ Accepted date: 15.06 .2020 \\ Published date: 15.06 .2020 \\ To cite this document:}

Tumbali, M. V. L. (2020). "Sharing Economy" The Case of Airbnb in NCR: An Honestly Significant Difference (HSD) Test. Journal of Tourism, Hospitality and Environment Management, 5 (19), 102-117.

DOI: $10.35631 / J T H E M .519008$.

\begin{abstract}
:
As opposed to the traditional market model, which is based on possession, the 'Sharing Economy' is based on sharing and utilizing services and products among others. Airbnb founded by Joe Gebbia and Brian Chesky in 2008, is one the best example of the Sharing Economy. The purpose of this paper was to determine and compare the market revenue and occupancy rates of the selected cities in the National Capital Region from 2016-2019. Secondary Data was from AirDNA - a paid service tool intentional for Airbnb researchers. One-way Anova was the statistical test used in this study, followed by an honestly significant difference (HSD) test. This research paper covered seven (7) selected cities in the National Capital Region. These are the City of Manila, Makati, Mandaluyong, Pasay, Parañaque, Pasig, and Quezon City. The results revealed that in the year 2016-2019 Manila appeared to have the highest percentage of occupancy rate, while Makati City gained the highest amount of Market Revenue.
\end{abstract}

\section{Keywords:}

Accommodation Services, Airbnb, HSD Test, Market Revenue, Occupancy Rate, Sharing Economy

\section{Introduction}

As more voyagers and even the individuals who go on 'staycation' presently book their accommodations through online booking - Airbnb. Airbnb is an online platform where landowners can lease their homes, lofts, and condominium suite units for short-term or longhaul lodgings. Short for Air Bed and Breakfast, it was founded by colleagues Joe Gebbia and Brian Chesky in 2008 and later on co-founded by Nathan Blecharczyk in San Francisco. According to a report in business mirror, this US\$30-billion company built 12 years ago cited 
the Philippines as one of its quickest developing markets in Southeast Asia, nearby other enormous neighboring economies like India, China, Singapore, Vietnam, and Malaysia (Pillas, 2015).

While on the other hand, over Manila Bulletin (2015), as reported by Bernie CahilesMagkilat, the Philippines is one of the Southeast Asian countries that utilize Airbnb. In 2015, JiaJih Chai, the Airbnb's overseeing chief for Southeast Asia and India told Manila Bulletin that Airbnb listings keep on developing in the Philippines. He included that it is additionally an astounding open door for Filipinos to gain some additional pay, particularly OFW who may go out and leave their house empty for quite a long time or months each year (Magkilat, 2015).

During his first time visit in Cebu, often called the 'Queen City of the South' and the Seat of Christianity in the Philippines and also the country's oldest city (Cebu Tourism website) last May 9-12, 2019, Airbnb chief strategy officer Nathan Blecharczyk talks at the Pacific-Asia Travel Association Summit at the Radisson Blu Hotel. According to the report of Cacho (2019) in SunStar Cebu, Blecharczyk, mentioned that:

"Setting the right expectation is a challenge. But this platform
offers a unique experience to connect to the destination and
individuals. We help spread tourism and wealth outside the
popular destinations, adding that once local communities open
up their homes for the travelers to stay, economic activities in
their area begin to flourish".

According to the Philippine Statistics Authority (PSA, 2019), poverty incidence among Filipino families in the first semester of 2018 was estimated at 16.1 percent. This is defined as the proportion of families whose income is below the poverty line to the total number of families. With this, as part of the hospitality professionals, the researcher wants to advance and scatter the comprehensive sharing economy model in the tourism industry sector most especially under the accommodation sector, which takes into consideration new progressions of chances or possibilities for low-income wagers and for those individuals who want extra income.

Today tourists and travelers are exploiting a lot more extensive scope of sharing economy experiences offered by local communities. It may be in the form of sharing food, (e.g Food Panda and Grab Food) online buying (e.g. Lazada and Amazon) or taking part in some other action, such as ride-sharing (e.g. Grab and Angkas) and lastly home-sharing (e.g. Airbnb) is an expeditiously developing business for sharing economy market platforms all operating and accessible in the Philippine setting.

It is a fact that Airbnb is able to offer a price competitive accommodation alternative to travelers (Forgács \& Dimanche, 2016). Subsequently the study of (Min \& Lu, 2017) indicates that the performance expectancy was the strongest predictor of why travelers intend to use Airbnb. In contrast, the study of (Heo, Blal \& Choi, 2019) confirmed that the volume of activity on the Airbnb platform is booming. However, they also show that performance results are mixed. The average occupancy has reached a plateau, ADR is slightly decreasing and profitability for hosts is dropping. 
As to date, Airbnb with 51 million listings worldwide, 81 thousand cities and 191 countries has 31 offices globally. Founded in 2008, Airbnb's mission is to make a world where people can have a place through healthy travel that is local, authentic, diverse, inclusive and sustainable. Airbnb uniquely leverages technology to economically empower a huge number of people around the world to unlock and monetize their spaces, passions and talents to become hospitality entrepreneurs. With encounters, Airbnb offers remarkable access to local communities and interests through 15,000+ unique, handcrafted activities run by hosts across $1,000+$ markets around the world. Airbnb's people-to-people platform benefits all its stakeholders, including hosts, guests, employees and the communities in which it operates. Airbnb lets people rent out their properties or spare rooms to guests. Airbnb takes 3\% commission of every booking from hosts, and between $6 \%$ and $12 \%$ from guests (Airbnb, 2019).

Seven cities in National Capital Region (NCR) were chosen for the reason that those seven cities have readily available data in AirDNA and these are: Pasay, Parañaque and Makati City that comprises the (4th district - Southern Manila), for (2nd district - Eastern Manila), these are: Mandaluyong, Quezon City, and Pasig. And lastly the city of Manila for the (1st district Capital district). However, no city was chosen from district 3. This study benefits the students, academicians and any individual who wants to invest in the near future to become a future Airbnb host. Moreover, this study serves as a basis for Local Government Authorities whether doing business with Airbnb is rewarding or detrimental. Furthermore, this investigation may assist the authorities by deciding whether this developing business sector is a risk or can add to the existing number of accommodation establishments to help future travelers in choosing for a more convenient alternative.

The motivation for this is to empirically contribute to the actual heated debate taking place worldwide by looking at a different market than those more typically covered by many academicians and researchers such as Consumer Behavior (Lutz \& Newlands, 2018; Amaro, Andreu, \& Huang, 2019; Mao \& Lyu, 2017), Pricing Strategy (Gibbs et al., 2018; Roma, Panniello, \& Nigro, 2019; Kwok \& Xie, 2018, and Safety and Security (Cheng \& Jin, 2019; Mattson-Teig, 2015; McNamara, 2015).

This study serves as a basic foundation for academicians, researchers, investors and local government authorities about the Airbnb. The purpose of this paper was to determine and compare the market revenue and occupancy rates of the selected cities in the National Capital Region from 2016-2019. The researcher believe that these are important metrics as they provide insight as to how competitive Airbnb might be with traditional accommodation services in a particular market. Also, this study aims to find out the honestly significant differences in market revenue and occupancy rates among the seven cities. Moreover, this study aimed to determine if Airbnb has any prospect of opportunities to any individual. Market revenue and Occupancy rates are two most common key performance indicator of success in an accommodation establishment. And lastly, this study contributes to the body of knowledge of sharing economy (Airbnb) by redefining the term Sharing Economy in the case of Airbnb by summarizing all the definition made by previous researchers. To answer the above objectives, the researcher come up with these hypotheses:

Ha1: There is a significant relationship among the selected seven cities with regards to occupancy rates.

Ha2: There is a significant relationship among the selected seven cities with regards to market revenue. 
Ha3: There is an honestly significant difference among the seven cities in Metro Manila with regards to occupancy rates and market revenue.

\section{Literature Review}

\section{"Sharing Economy" In the Case of Airbnb}

The sharing economy has become an opportune topic in both academic and popular debates. As of writing and after multiple articles and journals that the researcher has read, there were numerous authors that had their own definition of Sharing Economy compared three (3) years ago when the researcher had her first time encountering the term Airbnb. To sum it up, here are the following: As defined by Frenken \& Schor (2019), 'Sharing Economy' signifies purchasers allowing each other temporary access to under-utilized physical assets (idle capacity), perhaps for cash. While Schor (2014), mentioned that, one clarification for the sharing economy's brilliant development is that it has to a great extent, been depicted as a positive advancement, which means organizations are quick to connect with it. The issue of vulnerability and trust could be all the more baffling for guests to some degree in light of the impression of Airbnb as a sharing economy. Airbnb has been considered as an example of a sharing economy, at any rate toward the start of its advancement (Yannopoulou et al., 2013). Moreover, Roelofsen (2018), stated that the platform seemingly rotates around a generally core thought of home as a position of 'having a place'. Another definition came from (NESTA and Collaborative Lab, 2014) - Sharing economy organizations are online platforms committed to exchange of products and ventures among suppliers and clients. Models incorporate BlaBlaCar.com or Airbnb.com (from this point forward alluded to just as 'BlaBlaCar' and 'Airbnb').

Travelers are getting a charge out of the numerous preferences of accommodations these days. Guests can book even peak season or hours in light of this burgeoning platform. Individuals and organizations that take part in business exercises in the sharing economy are exceptionally motivated as consumers have flagged their acknowledgment of new provider assets, innovation encouraged exchanges, and elective channels (Thorne \& Quinn, 2017). In Sydney, Australia numerous individuals are utilizing Airbnb such that fits the sharing economy account and lines up with how the platform is promoted. House sharing is likewise not a new practice, obviously, with Bed and Breakfasts, share houses and lodging already prevalent before Airbnb's arrival (Crommelin, Troy, Martin \& Pettit, 2018).

The sharing economy has started to change numerous parts of life. In the changing states of market interest, the methodology of new economic models to advance the sharing of underutilized resources is frequently referred to as 'access over ownership': rather than owning things in our lives - particularly things that are rarely utilized or costly - we can get to them when and how we need them. This model applies to a scope of advantages, from carsharing and bicycle sharing to shared workspace, shared apparatuses and substantially more (Psarros, Rinne, Jordan \& Pastras, 2016).

Through Airbnb, connections may extend from being simply familial to becoming also entrepreneurial, achieving an entirely different arrangement of obligations towards one another (Roelofsen, 2018). His study also added that in some cases, leasing home through Airbnb has incited in certain family units a re-division of work in "making-home" among one another. Airbnb effectively conveys quantifiable and pertinent focal points in defeating distance, saving time, and for the most part, figuring out how to offer a solution for a "pain point" be it obliged travel spending plan or an inclination for a given area. Airbnb likewise offers the view of control for users, and apparent credible involvement with local people 
(Forgacs \& Dimanche, 2016). The convenience created by Sharing Economy encompass ondemand access to services and goods, proficient use of unused resources prompting to advanced education, expanded employment, and rising entrepreneurship skills (Braid, 2017).

Above all this definition, the common denominator is that Sharing Economy is simply providing additional access of resources for the society and economy. Moreso, Airbnb has seen to be growing positively in different countries and it's really making other individuals to grow even more and to be productive. The researcher has come to define also the Sharing Economy (Airbnb) that will add to the growing literature of Airbnb and Sharing Economy that is:

- The Sharing Economy in the case of Airbnb is based on implementing, sharing and utilizing services and products among other people in the society with the use of an online platform that can attract more travelers to stay in one tourism destination. This means that providing additional accommodation choices for any tourist and travelers can have an impact to the growing number of tourist arrivals per country yearly.

\section{Revenue}

The present study followed the Philippine Statistics Authority's (PSA, 2012) definition of revenue - the value of goods, products/by-products sold and/or services rendered to others regardless of whether paid in cash or is viewed as receivable by the establishment. Additionally, valuation of products/by-products sold ought to be in producer's value, net of allowances and discounts, including charges and duties however barring sponsorships. It likewise incorporates merchandise moved as well as services rendered to other establishments having a place with a similar endeavor as the said establishment which ought to be treated as sales or as though offered to a client or customer; and revenue from items on a legally binding premise from materials provided by the establishment.

According to Forgacs \& Dimanche (2016), one reason why the plan of action of Airbnb is fruitful is that they create a consistent revenue stream dependent on the transaction fees. This is evident in the work of Kwok \& Xie (2018) that shows a significantly larger revenue performance of a listing managed by a multi-listing host. Multi-listing host in Airbnb implies that a host has more than two (2) listings in the platform. It is fascinating that a multi-listing host would amplify the constructive outcome of value situating on revenue performance through pricing the listing at a higher expense level contrasted with the normal cost of different partners.

Airbnb listings are usually managed by the so called "Airbnb Host" according to their website. The professional hosts are able to command higher prices than non-professional hosts. On this point, it should be noted that professional hosts are those who manage two or more accommodations simultaneously (Magno, Cassia \& Ugolini, 2018) or the so called 'multi-host' as per (Kwok \& Xie, 2018). Thus, they can improve their skills more rapidly than non-proficient hosts. It guarantees that this impact is identified with the level of host involvement with advertising and price management, which is quite low toward the start however escalates after some time (Magno, et al., 2018). Summary of their study manifest that more professional hosts are able to gain some revenue management competences and to set higher prices. 


\section{Occupancy Rates}

The present study again adopted the definition from (PSA, 2012) for occupancy rate as the ratio of the number of occupied rooms to the number of available rooms. While Investopedia connotes that this rate assists experts with understanding changes in the private and business real estate markets and are regularly utilized in assessing resorts and hotel properties. Added to that, occupancy rates can likewise be applied to emergency hospital beds, residential buildings or even whole urban areas to check trends underlying economic activity.

As part of the hospitality industry practitioner, we calculate occupancy rate by dividing the total number of rooms occupied, by the total number of rooms available, and then multiply it by $100 \%$. It is one of the most well-known Key Performance Indicator (KPI) in the hotel industry for revenue management, emphasizing how much of the room vacancy in a hotel is actually being utilized.

In the study of (Jeffrey, Barden, Buckley \& Hubbard, 2002), a number of studies have identified a close positive relationship between occupancy rates and profits such as the works of (Norkett, 1985; Evans, McDonagh \& Moutinho, 1989; and Russo, 1991). Moreover, it was also noted in their study that information such as occupancy rate provides the one generally reliable, accessible and transiently disaggregated methods for observing the occupancy performance of most likely hotel accommodation all over the world. They can present a subtle gauge of the fluctuating fortunes of individual lodgings and validate the distinguishing proof of patterns and changes within the hospitality industry.

Meanwhile authors Meng \& Siriwardana (2017), mentioned in their book that the performance of gazette hotels can be evaluated by the average occupancy rate (AOR) and average room rate (ARR). It also came out in their analysis that the significant increases in ARR, AOR, and available rooms indicate that Singapore's hotel sector is making a good financial gain. Consistent to the exploratory study of (Singh, Dev \& Mandelbaum, 2014) to examine the relationship between top-line scales of hotel operating performance (average daily rate, revenue per available room and occupancy rate) and bottom-line measures of profitability or they called 'flow-through', resulting to that average daily rate (ADR) and occupancy are significantly and positively related to net operating income per available room (NOIPAR) and gross operating profit per available room (GOPPAR).

In contrast, occupancy rates of hotels in NCR showed a small-scale decrease in the report of Bondoc (2018), for the initial half-year of 2018 Colliers saw Makati CBD's average occupancy rate drop to $67 \%$ contrasted with the $71 \%$ recorded in a similar period in 2017 . The Bay Area's occupancy rate slipped from $70 \%$ to $69 \%$. And even among the sub-areas that posted a higher occupancy rate in 2018 were Quezon City had 66\% fell to 62\% and PasigMandaluyong Area (71\% from 70\%). By this we can acknowledge the reality of Airbnb as a player to be recognized in the hospitality industry to be taken into account by future researchers about Sharing Economy.

\section{Research Gap}

Currently, there is a knowledge gap in the literature about Airbnb's presence in the Philippines. Following the study of Mendoza et al., (2018) which determined the determinant factors of Airbnb occupancy rate in the province of Batangas, the study of Chua, Chiu \& Bool, (2019) that determined the perceived behavior of individuals opting to engage in Airbnb and the most recent study of Tumbali \& Ong, (2020) which compared the occupancy 
rates of an Airbnb listings and economy Hotels in Metro Manila, this study aimed to contribute to the insufficient study about Airbnb listings and provide additional information to potential Airbnb entrepreneurs and also to the Philippine local government units as to how competitive Airbnb might be with traditional accommodation services. Given that Airbnb entered the Philippine market eight (8) years ago, only three studies were conducted in the country. The result of this study will help people understand the expeditious growth of Airbnb and their listings in the Philippines more specifically in those seven selected cities.

\section{Methods}

To test the proposed hypotheses, the researcher obtained the data from AirDNA (www.airdna.co), a data company that offers two main services: 1) MarketMinder is a web app displaying metrics for every Airbnb rental worldwide and 2) Investment Explorer is a web app combining Airbnb data with home value data. The data services of AirDNA have been used and endorsed by major hospitality institutions such as CBRE Hotels and used by many researchers such as (Kwok \& Xie, 2018; Horn \& Merante, 2017; Dogru, \& Pekin, 2017). A grounded theory approach was then used in analyzing the data to know whether doing business with Airbnb is detrimental or rewarding.

The data acquired from AirDNA includes the monthly market revenue performance and occupancy rates of the listings in seven (7) major Airbnb markets in the Metro Manila. The available data from AirDNA is large-scale, but since the researcher has solely expense and had tight budget with this study, yet granular data was provided, consisting of over a total of 35 months from September 2016 to July 2019 for market revenue while a total of 36 months from August 2016 to July 2019 for occupancy rates.

The present study was purely quantitative in nature, data purchased from AirDNA - a paid service tool intended for Airbnb researchers. This study utilized the Tukey HSD ('honestly significant difference' or 'honest significant difference') test. It is a statistical instrument used to ascertain whether the connection between two or more arrangements of information is statistically significant - that is, regardless of whether or not there's a strong possibility that an observed numerical change in one value is causally related to an observed change in another value. In other words, Tukey test is a technique to test an experimental hypothesis (Lee \& Lee, 2018).

The test invoked to decide whether the inter-relatedness among the seven cities with two variables are conjointly statistically significant, which lamentably is not just an aggregate or result of the individual degrees of significance. In the choice of different correlation strategies, it is critical to consider the exact circumstances. The standard of choice is the capacity to control familywise $\alpha$ error level and the degree of power detecting significant difference (Kim, 2015).

To test whether market revenue and occupancy rates have significant relationship, the researcher utilized the One-way ANOVA. The most regularly utilized in comparing two means is the purported ("pairwise comparison"). A simple and frequently utilized pairwise comparison method was created by Tukey under the name of the honestly significant difference (HSD) test. The fundamental thought of the HSD is to figure the honestly significant difference between two methods utilizing a measurable conveyance characterized by Student and called the $q$ distribution. This distribution gives the specific sampling distribution of the biggest contrast between a set of means originating from a similar populace. All pairwise differences are assessed using a similar sampling distribution utilized 
for the biggest difference. This makes the HSD approach very traditionalist (Abdi \& Williams, 2010).

Subsequent to testing, the researcher took advantage of the Tukey HSD test to know whether there was a significant difference among the chosen seven urban communities. Some researchers, in general, anticipate that there is a significant difference from their variables, however to know well, HSD test or Tukey test was utilized with the help of Statistical Package for the Social Sciences (SPSS) version 25 to determine whether there is actually a noteworthy distinction among the selected areas in NCR.

This study discussed the findings that were retrieved from the test that had been done on the SPSS data. The test had been done on the Descriptive test, ANOVA test and also the HSD test with a total of 252 months for occupancy rates and a total of 245 months for market revenue. Data was gathered from last quarter of 2019.

\section{Results and Discussions}

Table 1: Occupancy Rates (Summary Statistics)

\begin{tabular}{|l|r|l|r|}
\hline & $\mathrm{N}$ & Mean & $\begin{array}{c}\text { Std. } \\
\text { Deviation }\end{array}$ \\
\hline Pasig & 36 & 46.4167 & 10.73679 \\
Manila & 36 & 63.8889 & 9.07360 \\
Makati & 36 & 63.4722 & 8.50037 \\
Quezon City & 36 & 48.5000 & 5.99762 \\
Mandaluyon & 36 & 56.2778 & 6.66166 \\
g & 36 & 29.9444 & 5.99020 \\
Paranaque & 36 & 56.6944 & 11.44882 \\
Pasay & 252 & 52.1706 & 13.89311 \\
Total & &
\end{tabular}

Table 2: Result of Occupancy Rates (One-way ANOVA)

\begin{tabular}{|l|l|l|}
\hline $\boldsymbol{d} \boldsymbol{f}$ & $\boldsymbol{p}$-value & Interpretation \\
\hline 68.458 & .000 & Significant \\
\hline
\end{tabular}

Table 1 displayed the comparison of the means of seven cities in NCR, for the occupancy rates from AirDNA for a total of 36 months each city, $(\mathrm{N}=36)$. Evidently, Manila got the highest mean of $63.89 \%$, seconded by Makati City which has $63.47 \%$, followed by the City of Pasay which has 56.69\%. Furthermore, Mandaluyong City comes after with $56.27 \%$, and next was Quezon City with $48.50 \%$. Follow in order was Pasig City which has $46.41 \%$ and last on the table was the City of Parañaque which has the least means above all of $29.94 \%$. This states that among the selected seven cities in NCR, Manila has the highest percentage in terms of occupancy rates, which means that Airbnb users in the Philippines usually booked a unit under Airbnb in the Manila area, while a lower percentage of Airbnb users booked at Parañaque City. This hold true at the macro level; where markets with higher occupancy have the highest number of Active Airbnb units (Lane \& Woodworth, 2016). 
Table 2 revealed the degrees of freedom which is 68.458 as well as the p-value $=.000$ (accept the alternative hypothesis) which indicates that there is a significant positive relationship among the selected seven cities with regards to occupancy rate. Tukey test was done after finding out that there is a noteworthy distinction among seven urban areas with respect to occupancy rates.

Table 3: Tukey Test for Occupancy Rates

\begin{tabular}{|c|c|c|c|c|c|c|c|}
\hline & PASIG & MANILA & MAKATI & $\underset{\text { CITY }}{\text { QUEZON }}$ & MANDALUYONG & PARAÑAQUE & PASAY \\
\hline PASIG & --- & $.000 *$ & $.000 *$ & .947 & $.000 *$ & $.000 *$ & $.000 *$ \\
\hline MANILA & $.000^{*}$ & --- & 1.000 & $.000 *$ & $.004 *$ & $.000 *$ & $.008 *$ \\
\hline МАКАТІ & $.000 *$ & 1.000 & -- & $.000 *$ & $.008 *$ & $.000 *$ & $.016 *$ \\
\hline QUEZON CITY & .947 & $.000^{*}$ & $.000^{*}$ & -- & $.003 *$ & $.000 *$ & $.001 *$ \\
\hline MANDALUYONG & $.000 *$ & $.004 *$ & $.008 *$ & $.003 *$ & --- & $.000^{*}$ & 1.000 \\
\hline PARAÑAQUE & $.000 *$ & $.000 *$ & $.000 *$ & $.000 *$ & $.000 *$ & --- & $.000 *$ \\
\hline PASAY & $000 *$ & $.008 *$ & $.016^{*}$ & $.001^{*}$ & 1.000 & $.000^{*}$ & --- \\
\hline
\end{tabular}

*The mean difference is significant at the 0.05 level.

This test analyzed every conceivable pair of means, to discover which specific groups' means contrasted with each other are unique. Table 3 revealed that Pasig has a statistically HSD among Manila, Makati, Mandaluyong, Parañaque and Pasay City with a significant value of .000. However, as shown on the table it was only Quezon City which has no significant HSD in Pasig City with a significant value of .947. On the other hand, Manila has a statistically HSD among Pasig (sig dif $=.000)$, Quezon City (sig dif $=.000$ ), Mandaluyong (sig dif $=$ .004 ), Parañaque (sig dif $=.000$ ) and Pasay City ( $\operatorname{sig}$ dif $=.008$ ). It was only Makati City which has no HSD in the City of Manila with a significant value of 1.000. Lastly, as highlighted on the table Mandaluyong has a statistically HSD among Manila (sig dif $=.004$ ), Makati (sig dif $=.008$ ), Pasig (sig dif $=.000)$, Parañaque (sig dif $=.000$ ) and Quezon City (sig dif $=.003$ ). It was found that merely Pasay City has no HSD with Mandaluyong City.

Tukey HSD was used to find the means that are significantly different within the seven (7) groups of cities. From Tukey HSD table for occupancy rates, we can conclude that all the above-mentioned cities have the source for this difference except for Parañaque City. Considering that it has is a $2.39 \%$ growth rate by highly urbanized city following Mandaluyong (3.12\%) and Taguig having the biggest growth rate among the 16 cities in NCR of $4.32 \%$. (See Appendix 1). This can be concluded that there are least number of Airbnb users in the said community. 
Table 4: Market Revenue (Summary Statistics)

\begin{tabular}{|l|r|r|r|}
\hline & \multicolumn{1}{|c|}{} & & \\
& $\mathrm{N}$ & \multicolumn{1}{c|}{ Mean } & \multicolumn{1}{c|}{ Std. Deviation } \\
\hline Pasig & 35 & 7781330.1143 & 4036142.28779 \\
Paranaque & 35 & 13340685.3429 & 5729242.26903 \\
Makati & 35 & 54818158.7143 & 16033365.29912 \\
Pasay & 35 & 26863348.5429 & 18374957.81784 \\
Quezon City & 35 & 31058211.0571 & 16559937.00586 \\
Mandaluyong & 35 & 20240430.8857 & 8192784.51615 \\
Manila & 35 & 13573963.6286 & 5267087.87884 \\
Total & 245 & 23953732.6122 & 18903708.41727 \\
\hline
\end{tabular}

Table 5: Result of Occupancy Rates (One-way ANOVA)

\begin{tabular}{|l|l|l|}
\hline $\boldsymbol{d} \boldsymbol{f}$ & $\boldsymbol{p}$-value & Interpretation \\
\hline 60.762 & .000 & Significant \\
\hline
\end{tabular}

Table 4 showed the comparison of the means of seven cities in NCR, for the market revenue from AirDNA for a total of 35 months each city, $(\mathrm{N}=35)$. It is apparent that Manila got the highest mean of 54,818,158.71, seconded by Mandaluyong City which has 31,058,211.06, followed by Quezon City which has 26,863,348.54. Furthermore, Pasay City comes after with 20,240,430.89, and next was Makati City with 13,573,963.63. Subsequently was Parañaque City with 13,340,685.34 and last on the table was the City of Pasig which has the least means above all of 7,781,330.11. This stated that among the selected seven cities in NCR, Manila has the highest mean in terms of Market Revenue, which means that Airbnb users in the Philippines usually booked a unit in the Manila area. With reference to table 4, it depicted that the higher the occupancy rates, the higher the market revenue is. Meanwhile, it was reflected in table 4 that Pasig City has the least market revenue. However, as revealed in table 1, Parañaque got the lowest mean in terms of occupancy rates. It could be asserted that Airbnb listings in Pasig City is much cheaper than listings in Parañaque.

Table 5 likewise indicated the output of the ANOVA investigation and whether there was a statistically significant relationship among the seven urban areas with regards to their market revenue. As showed over, the significance value is .000 (i.e., $p=.000$ (accept the alternative hypothesis)), which is underneath 0.05 and, therefore, in this manner, there is a statistically significant relationship among the seven urban areas in NCR concerning their market revenue. 
Table 6: Tukey Test for Market Revenue

\begin{tabular}{|c|c|c|c|c|c|c|c|}
\hline & PASIG & MANILA & MAKATI & $\mid \begin{array}{c}\text { QUEZON } \\
\text { CITY }\end{array}$ & MANDALUYONG & PARAÑAQUE & PASAY \\
\hline PASIG & --- & .408 & $.000 *$ & $.000 *$ & $.000 *$ & .460 & $.000 *$ \\
\hline MANILA & .408 & --- & $.000 *$ & $.000 *$ & .240 & 1.000 & $.000 *$ \\
\hline МАКАТІ & $.000 *$ & $.000 *$ & --- & $.000 *$ & $.000 *$ & $.000 *$ & $.000 *$ \\
\hline QUEZON CITY & $.000 *$ & $.000^{*}$ & $.000^{*}$ & --- & $.004 *$ & $.000 *$ & .769 \\
\hline MANDALUYONG & $.000^{*}$ & .240 & $.000 *$ & $.004 *$ & --- & .203 & .247 \\
\hline PARAÑAQUE & .460 & 1.000 & $.000^{*}$ & $.000 *$ & .203 & --- & $.000 *$ \\
\hline PASAY & $000 *$ & $.000 *$ & $.000 *$ & .769 & .247 & $.000 *$ & --- \\
\hline
\end{tabular}

*The mean difference is significant at the 0.05 level.

Table 6 uncovered that Pasig has a statistically HSD among Quezon City, Makati, Mandaluyong, and Pasay City with a common significant value of .000. However, as appeared on the table it was Manila and Parañaque which has no HSD in Pasig City with a significant value of .408 and .460 . On the other hand, Manila has a factually HSD among Makati, Quezon City and Pasay with a congruent significant value of (sig dif = .000). Conversely, Manila has no HSD with Mandaluyong City (sig dif $=.240$ ) and Parañaque City (sig dif $=1.000$ ). In addition, Quezon City has a statistically HSD among Pasig, Manila, Makati, Parañaque City with an equal value of (sig dif $=.000)$ and Mandaluyong with (sig dif $=.004$ ). As evident, it was solely Pasay City which has no HSD with (sig dif $=.769$ ). Moreover, as reflected on the table Mandaluyong City has no HSD among Parañaque (sig dif $=.203$ ) and Pasay City (sig dif $=.247$ ). Above all seven cities, it was apparent that Makati City has statistically HSD among all each other.

This can be concluded that above all seven cities merely Makati City has no HSD in six other cities with regard to market revenue. This can be noted for future exploratory study given that Makati City is considered as the country's financial hub. It's known for the skyscrapers and shopping malls of Makati Central Business District. It can be seen that individuals from Makati City are not fund of using Airbnb as their accommodation conceivably because majority residing there are business people who intend to use hotel as their preference similar to the report of Colliers (2019) that hotels remain the preferred accommodation of business travelers especially in key business hubs such as Makati.

As per property consultancy Colliers International Philippines (2019), there's an increased demand for short-term leasing from remote and local explorers, millennials, and yuppies who are available to Airbnb's shared economy model, and OFWs who are on a short excursion in the Philippines. Some Filipinos, without a doubt, bring in cash through Airbnb hosting. Posting a condominium suite or the entire house unit on the Airbnb application can earn you as much as PHP 50,000 per month. Indeed, you're making money from your investment, so it helps if someone have an entrepreneurial mindset.

The sharing economy is related to difficulties as well as opportunities, which is the reason why numerous societies and economies around the world are at present investigating how they could improve their insight on the phenomenon (Psarros, Rinne, Jordan and Pastras, 
2016). The idea of individuals' mobility stipulates that Airbnb enables remote tourism destinations to create the tourism industry enterprises by expanding travelers' length of stay. Moreover, the formation of business opportunities in these remote areas can stimulate the entire production network, especially generating employment opportunities (Cheng \& Edwards, 2017). The findings of the study were comparable with the report of Jordan (2015), that states that Airbnb does not only expand the supply of available rooms but also reduce conventional hotel revenue on high demand dates by up to $40 \%$ (Jordan, 2015).

As a pure Filipino, we people are born to be hardworking and resourceful. This investigation benefits the entire Filipino community that is anxious to gain beyond what they can, Overseas Filipino Worker (OFW), millennials, yuppies (young professionals) and even senior citizens who are now retired or can't able to accomplish physical work anymore, provided that they will hire their own caretaker.

\section{Conclusions and Recommendations}

As per Colliers (2018), reported by Bondoc, notwithstanding the continuous increase in international arrivals, the hotel average occupancy across Metro Manila declined possibly from $70 \%$ in 2017 to $69 \%$ in 2018 . The figure moved toward the upper end of their occupancy conjecture of $65 \%$ to $68 \%$ for 2018 . While a majority of the short-term rental platforms have begun to make their significance over the last decade, it is Airbnb that has most influenced the activity of the tourism industry sector most especially under the accommodation sector and apparently set up the most grounded competition or threat to the traditional providers of the hotel industry as proven by some of the research works of (Guttentag \& Smith, 2017; Zervas, Proserpio, \& Byers, 2017; and Boros, et al., 2018). In light of the investigation, Airbnb has and will keep on infringing on the business of the traditional accommodation services.

This study concluded that there were actively travelers who uses Airbnb platform in the selected seven areas in NCR. With regards to occupancy rates, the City of Manila appeared to have the highest percentage, in view of the fact that Manila is the capital and second-biggest city of the Philippines and one of 16 urban areas that comprises Metro Manila, which has a general populace of 12.8 million as per the 2015 Census. The City of Manila has a populace of 1.78 million in the year 2016, as indicated by statistics information. On the other side, Parañaque City generated the lowest percentage in terms of occupancy rate, this perchance because there were only 665,822 population in the area as per the 2015 Census. From Tukey HSD table for occupancy rates, it was concluded that all the above-mentioned cities have the source for this difference except for Parañaque City. This can be assumed that there were least number of Airbnb users in the said community. Occupancy rate is one of the most elevated level indicators of success in selling rooms. This implied that there were higher rooms sold in Manila Area from 2016-2019 compared to other six cities. And that lower rooms sold in Parañaque City was noticed.

On the other hand, Market Revenue in Makati City appeared to have the highest figure for the year 2016-2019. This conveyed that even Manila got the most inflated rate with regards to occupancy rate, it doesn't imply that it will likewise have a high measure of market revenue. This is for the reason that prices/costs vary in different areas and it was also assumed that Airbnb listing in Makati City was higher in terms of price compared to Manila for the reason that it generated the highest revenue yet it was second in the rundown of the occupancy rate. Conversely, the most reduced figure was from Pasig City which derived that room costs in Pasig was somewhat less expensive than Parañaque City. This result calls for another 
investigation: comparing room prices in Airbnb listing in the areas where Airbnb is available. While from Tukey HSD table for market revenue, all seven cities excluding Makati City has no differences in six other cities. It was seen that individuals from Makati City are not fund of using Airbnb as their accommodation preference, this is due to the fact that majority residing there are business people who intend to use hotel as their preference similar to the report of Colliers (2019) that hotels remain the preferred accommodation of business travelers especially in key business hubs such as Makati.

Subsequent to seeing all the information from AirDNA, and in the wake of testing the accessible information from SPSS, the researcher surmised that having business with Airbnb in the Philippines is genuinely fulfilling and rewarding. Refining the definition of Sharing Economy in the case of Airbnb as it is based on implementing, sharing and utilizing services and products among other people in the society with the use of an online platform that can attract more travelers to stay in one tourism destination. This means that providing additional accommodation choices for any tourist and travelers can have an impact to the growing number of tourist arrivals per country yearly and that can help the tourism industry grow in the said country. There is nothing improper in attempting what business will suit an individual, the pivotal thing in doing business with Airbnb is you will benefit as well as helping the community in discovering accommodations when hotels are not accessible. This study was also a respond to the room gaps in identified tourism destinations as mentioned by the Philippine local government reported by Infrastructure and Services Industries Service (ISIS) - BOI last December 2017. The findings of this study can be of interest to the local government unit, particularly in the process of adopting development policies for the tourist accommodation establishments.

Implications of the study is that limited only within NCR. Likewise, the census tract population per city wasn't address if it has a relationship with regards to the revenue per listing. Suggesting that listings in more opulent tracts have not made as much money as those in less opulent ones. Moreover, due to incapacity of the researcher in terms of finance, limited data was purchased in AirDNA. Another restriction of this study that can add to the heated growing literature of Airbnb all throughout the world is to examine the characteristics of successful Airbnb host providers and determine what skills are needed to be successful.

The significant key to giving better Airbnb encounters to the clients as a host is to comprehend what the client's needs. The necessities of the Airbnb guests will change contingent upon the area they are visiting, the season, the explanation behind their travel, and their personal preferences (Adiera, 2019). Turning into an Airbnb host is the same as being a businessperson. You need to invest exertion, time, money and patience to make it beneficial and worth your speculation. Indeed, the saying "Patience is a virtue" may deem to be pivotal in doing a business. And just like setting up any business, you have to make some essential strides, such as conducting market research and making a marketable strategy, to guarantee you are starting the correct foot. Future researchers may want to scrutinize other areas of the Philippines to map out the after effect or Airbnb listings in the said country. Moreso, future researchers may have desire to other sharing economy platforms such as OYO and RedDoorz which are also making their names in the country. Be that as it may, considering there are numbers of the emerging markets as sharing economy platforms, it is imperative to recognize how to govern such business across the outskirts and whether this entails a way to deal with local government authorities under the tourism industry. And lastly, on the off chance that the future analysts have a spending limit, he/she can purchase from AirDNA to handle the rest of 
the urban areas in NCR such as: Caloocan, Malabon, Navotas, Valenzuela, , Marikina, Taguig, San Juan, Las Piñas, and Muntinlupa.

\section{References}

Abdi, H., \& Williams, L. J. (2010). Tukey's honestly significant difference (HSD) test. Encyclopedia of research design, 3, 583-585.

Adiera, R.M., Rahimc, A., Subasini, S., \& Nesamanyd, P. (2019). An Empirical Study on AIRBnB Accommodation Services and Customer Decision Making.

AirDNA.co. April 6, 2018. Retrieved from: https://medium.com/@AnalyzeMyAirbnb.com/airdna-marketminder-reviewanalysis$58 \mathrm{c} 8627 \mathrm{cf} 143$

Amaro, S., Andreu, L., \& Huang, S. (2019). Millenials' intentions to book on Airbnb. Current Issues in Tourism, 22(18), 2284-2298.

Bernie Cahiles-Magkilat (2015). Manila Bulettin. Retrieved from: https://www.pressreader.com/philippines/manila-bulletin/20150720/ 282106340327815

Bondoc, Joey Roi (2018). Colliers Quarterly PHILIPPINES | HOTEL 2Q 201813 August 2018. Retrieved from: https://www.colliers.com//media/files/marketing\%20reports/colliers_manila_industria 1_q2_2018_final.pdf?la=en-gb

Boros, L., Dudás, G., Kovalcsik, T., Papp, S., \& Vida, G. (2018). Airbnb in Budapest: analysing spatial patterns and room of hotels and peer-to-peer accomodations. GeoJournal of Tourism and Geosites, 10(1), 26-38.

Braid, Florangel Rosario July (2017). A shared economy Retrieved from: https://news.mb.com.ph/2017/07/07/a-shared-economy/

Cacho, Katlene (2019). SunStar Cebu. Airbnb vows to work with governments. Released Date: May 10, 2019. Retrieved December 10, 2019 https://www.sunstar.com.ph/article/1805090

Cheng, M., \& Jin, X. (2019). What do Airbnb users care about? An analysis of online review comments. International Journal of Hospitality Management, 76, 58-70.

Colliers International Philippines (2019). Airbnb: Friend or Foe? Retrieved from: https://www.colliers.com/en-gb/philippines/about/media/airbnb-friend-or-foe

Dogru, T., \& Pekin, O. (2017). What do guests value most in Airbnb accommodations? An application of the hedonic pricing approach.

Forgács, Gábor \& Dimanche, Frederic. (2016). Revenue challenges for hotels in the sharing economy: Facing the Airbnb menace. Journal of Revenue and Pricing Management. 15. 10.1057/s41272-016-0071-z.

Frenken, K., \& Schor, J. (2019). Putting the sharing economy into perspective. In A Research Agenda for Sustainable Consumption Governance. Edward Elgar Publishing.

Gibbs, C., Guttentag, D., Gretzel, U., Morton, J., \& Goodwill, A. (2018). Pricing in the sharing economy: a hedonic pricing model applied to Airbnb listings. Journal of Travel \& Tourism Marketing, 35(1), 46-56.

Guttentag, D. A., \& Smith, S. L. (2017). Assessing Airbnb as a disruptive innovation relative to hotels: Substitution and comparative performance expectations.

International Journal of Hospitality Management, 64, 1-10.

Heo, C. Y., Blal, I., \& Choi, M. (2019). What is happening in Paris? Airbnb, hotels, and the Parisian market: A case study. Tourism Management, 70, 7888. doi: 10.1016/j.tourman.2018.04.003

Horn, K., \& Merante, M. (2017). Is home sharing driving up rents? Evidence from Airbnb in Boston. Journal of Housing Economics, 38, 14-24. 
Jeffrey, D., Barden, R. R. D., Buckley, P. J., \& Hubbard, N. J. (2002). What Makes for a Successful Hotel? Insights on Hotel Management Following 15 Years of Hotel Occupancy Analysis in England. The Service Industries Journal

Jordan, G. (2015). Airbnb not just a worry, but 'tectonic shift'. Hotel News Now, 26.

Kim, H.-Y. (2015). Statistical notes for clinical researchers:post-hocmultiple comparisons. Restorative Dentistry \& Endodontics, 40(2), 172. doi:10.5395/rde.2015.40.2.172

Kwok, L., \& Xie, K. L. (2018). Pricing strategies on Airbnb: Are multi-unit hosts revenue pros? International Journal of Hospitality Management. doi: 10.1016/j.ijhm.2018.09.013

Lane, J., \& Woodworth, R. M. (2016). The sharing economy checks in: An analysis of Airbnb in the United States. CBRE Hotel's Americas Research.

Laura Crommelin, Laurence Troy, Chris Martin \& Chris Pettit (2018): Is Airbnb a sharing economy superstar? Evidence from five global cities, Urban Policy and Research, DOI: $10.1080 / 08111146.2018 .1460722$

Lee, S., \& Lee, D. K. (2018). What is the proper way to apply the multiple comparison test? Korean journal of anesthesiology, 71(5), 353-360. doi:10.4097/kja.d.18.00242

Lutz, C., \& Newlands, G. (2018). Consumer segmentation within the sharing economy: The case of Airbnb. Journal of Business Research, 88, 187-196.

Magno, F., Cassia, F., \& Ugolini, M. M. (2018). Accommodation prices on Airbnb: effects of host experience and market demand. The TQM Journal, 30(5), 608620. doi:10.1108/tqm-12-2017-0164

Manolis Psarros, April Rinne, Peter Jordan and Pantazis Pastras (2016). Sharing Economy and the TOURISM and HOSPITALITY SECTOR in GREECE. Toposophy. Destination Marketing Agency

Mao, Z., \& Lyu, J. (2017). Why travelers use Airbnb again? International Journal of Contemporary Hospitality Management.

Mattson-Teig, B. (2015). Residential managers police AIRBNB" guests". Journal of Property Management, 80(5), 32-37.

McNamara, B. (2015). Airbnb: A not-so-safe resting place. Colo. Tech. LJ, 13, 149. [Google Scholar]

Mendoza, J. V. B., Aquino, J. M. F., Briones, K. M., Geralde, J. M. C., Macasaet, J. M. G., Mirambil, A. R. S., \& Meñez, M. F. L. (2018). Determinant Factors of Airbnb Occupancy Rate in the Province of Batangas, Philippines. Journal of Tourism and Hospitality Research, 15(1).

Meng, S., \& Siriwardana, M. (2017). Assessing the Economic Impact of Tourism. doi:10.1007/978-3-319-40328-1 [ebook]

Min, Wang \& Lu, Li. (2017). Who Wants to Live Like a Local?: An Analysis of Determinants of Consumers' Intention to Choose AirBNB. 642-651. 10.1109/ICMSE.2017.8574467.

Mingming Cheng \& Deborah Edwards (2017): A comparative automated content analysis approach on the review of the sharing economy discourse in tourism and hospitality, Current Issues in Tourism, DOI: 10.1080/13683500.2017.1361908

NESTA and Collaborative Lab (2014) Making Sense of the UK Collaborative Economy, Available from: http://www.nesta.org.uk/publications/making-sense-ukcollaborative-economy

Philippine Statistics Authority (PSA), Release Date: 13 January $2012 . \quad$ Retrieved December 8, 2018 from: https://psa.gov.ph/hotels-resto/step-id/1569

Philippine Statistics Authority (PSA), 10 April 2019. Retrieved December 18, 2019 from: https://psa.gov.ph/poverty-press-releases/nid/138411 
Pillas, Catherine (July, 2015) Airbnb executive hails PHL as fastest-growing in Asean Retrieved from: https://businessmirror.com.ph/2015/07/07/airbnb-executivehails-phl-as-fastest-growing-in-asean/

Roelofsen, M. (2018) Performing "home" in the sharing economies of tourism: the Airbnb experience in Sofia, Bulgaria. Fennia 196(1) 24-42. https://doi.org/10.11143/fennia.66259

Roma, P., Panniello, U., \& Nigro, G. L. (2019). Sharing economy and incumbents' pricing strategy: The impact of Airbnb on the hospitality industry. International Journal of Production Economics, 214, 17-29.

Schor, J. (2014). Debating the Sharing Economy. Great Transition Initiative. Retrieved from greattransition.org/publication/debating-the-sharing-economy

Singh, A., S. Dev, C. and Mandelbaum, R. (2014), "A flow-through analysis of the US lodging industry during the great recession", International Journal of Contemporary Hospitality Management, Vol. 26 No. 2, pp. 205224. https://doi.org/10.1108/IJCHM-12-2012-0260

Tumbali, M. V. L., \& Ong, E. G. (2020). AIRBNB AND ECONOMY HOTELS IN METRO MANILA: A COMPARATIVE ANALYSIS. International Journal of Accounting, 5(26), 107-117.

Yannopoulou, N., Moufahim, M., \& Bian, X. (2013). User-generated brands and social media: Couchsurfing and Airbnb. Contemporary Management Research, 9(1), 8590

Zervas, G., Proserpio, D., \& Byers, J. W. (2017). The rise of the sharing economy: Estimating the impact of Airbnb on the hotel industry. Journal of marketing research, 54(5), 687-70 